\title{
The management of chronic hepatitis C: 2018 guideline update from the Canadian Association for the Study of the Liver
}

\author{
Hemant Shah MD MScCH(HPTE), Marc Bilodeau MD, Kelly W. Burak MD MSc, Curtis Cooper MD, Marina Klein MD MSc, \\ Alnoor Ramji MD, Dan Smyth MD, Jordan J. Feld MD MPH; for the Canadian Association for the Study of the Liver
}

Cite as: CMAJ 2018 June 4;190:E677-87. doi: 10.1503/cmaj.170453

CMAJ Podcasts: author interview at https://soundcloud.com/cmajpodcasts/170453-guide

See related article at www.cmaj.ca/lookup/doi/10.1503/cmaj.170931

hronic hepatitis C virus (HCV) is a highly burdensome public health problem in Canada, causing more years of life lost than any other infectious disease in the country. ${ }^{1-3} \mathrm{~A}$ recent modelling study suggested that about 252000 Canadians (uncertainty interval: 178000-315000 Canadians) were chronically infected in 2013. The birth cohort of 1945-1975 has the highest prevalence of chronic HCV infection, yet it is estimated that up to $70 \%$ of this group have not been tested for HCV. ${ }^{4}$

Although the overall prevalence of chronic hepatitis $C$ is declining, complications of the disease are increasing because of aging of the infected population and progression of liver fibrosis. ${ }^{1-3}$ Modelling data suggest that if nothing is done to change the current situation, cases of decompensated cirrhosis, hepatocellular carcinoma and liver-related mortality will increase by $80 \%, 205 \%$ and $160 \%$, respectively, by 2035 compared with 2013 levels. $^{2}$

The primary objective of anti-HCV therapy is complete eradication of the virus, termed a sustained virologic response, which is defined as absence of viremia 12 weeks after completion of therapy. ${ }^{5}$ Once achieved, sustained virologic response is considered a true cure of the viral infection, as late relapses are very uncommon. ${ }^{6,7}$ Sustained virologic response is associated with long-term health benefits that include improved quality of life ${ }^{8,9}$ and liver histology, ${ }^{10,11}$ and reduced incidence of hepatocellular carcinoma, ${ }^{12}$ liver-related morbidity and mortality, ${ }^{13-15}$ and all-cause mortality. ${ }^{12}$

Since the last Canadian guideline on the management of chronic HCV infection from the Canadian Association for the Study of the Liver was published in $2015,{ }^{16}$ there have been remarkable treatment advances. Thus, there was a need for an updated, evidence-based guideline.

\section{Scope}

This guideline was written to assist physicians and other health care professionals in the management of adult patients with chronic HCV infection. To support clinical practice, it makes rec-

\section{KEY POINTS}

- Hepatitis $\mathrm{C}$ is a major public health problem in Canada that is underdiagnosed and undertreated; birth cohort screening would benefit population health outcomes.

- Pretreatment evaluation of an infected patient should include clinical evaluation, viral load, genotype and a fibrosis stage assessment.

- The treatment of hepatitis $\mathrm{C}$ has become safer, better tolerated and more effective owing to the availability of direct-acting antivirals for nearly all patients; this guideline advocates against the use of any interferon-based treatment regimens and for the use of all-oral regimens for all infected patients.

- The treatment of infected patients should be individualized to maximize chance of success, especially for difficult-to-cure populations, including patients with renal failure, decompensated cirrhosis, and active substance use disorders.

- After treatment, the follow-up of successfully treated patients depends on whether they are cirrhotic; patients with cirrhosis require life-long surveillance for the development of hepatocellular cancer.

ommendations on the assessment, evaluation and management of HCV-infected persons. Treatment recommendations are given for specific patient populations divided by HCV genotype (and subtype), treatment history (naive or experienced) and the presence or absence of cirrhosis. Subpopulations with special considerations are discussed individually, including chronic kidney disease, decompensated cirrhosis, post-liver transplant, people who inject drugs and acute HCV infection. This guideline does not address HIV/HCV coinfection, and we refer readers to the existing Canadian guideline for this population. ${ }^{17}$

\section{Methods}

\section{Guideline panel composition}

The Executive Committee of the Canadian Association for the 
Study of the Liver appointed two co-chairs of the guideline panel (H.S. and J.F.). The co-chairs selected six other members of the guideline panel based on their expertise in specific areas of HCV management, including hepatology, infectious disease, public health, clinical care, research and epidemiology.

\section{Guideline development}

Two panel members were assigned to each guideline section (epidemiology, screening, treatment indications and contraindications, pretreatment assessment, antiviral therapy [genotype 1 (G1) naive, $\mathrm{G} 1$ experienced, $\mathrm{G} 2, \mathrm{G} 3, \mathrm{G} 4, \mathrm{G} 5 / 6$ ], resistance, special populations [chronic kidney disease, decompensated cirrhosis, liver transplant, people who use drugs, acute HCV, direct-acting antiviral failures]), one to serve as the primary section author and the other as a secondary reviewer. A focused literature search for both published and unpublished literature was undertaken to update the evidence base used in the 2015 guideline. In brief, the literature search was conducted in MEDLINE (Jan. 15, 2015 to Oct. 31, 2016), using the following search terms: hepatitis $C$, hepatitis and treatment. English-language articles were included. There were no other exclusion criteria. The literature search was updated (Oct. 17,2017 ) before publication to capture any recent studies.

Section authors screened the search results for studies relevant to their section topics. Potentially relevant citations were retrieved and reviewed in full text, as well as unpublished abstracts presented at international hepatology and infectious disease conferences. Abstract authors were contacted to provide additional details as required. After review of the relevant 2015 guideline recommendations, the primary author for each section drafted the new recommendations and graded the supporting evidence, using the rating scheme from the American College of Cardiology Foundation and the American Heart Association practice guideline, ${ }^{18,19}$ as used in similar practice guidelines by the Canadian Association for the Study of the Liver. ${ }^{20}$ Recommendations were assigned a class (reflecting benefit versus risk) and level of evidence (assessing strength of certainty) (Box 1).

The secondary author reviewed recommendations and supporting evidence for each section, and any disagreements were resolved by consensus. In most cases, the text of the 2015 guideline was modified for this update. The entire guideline panel then reviewed all recommendations and supporting evidence through dedicated recorded teleconferences. For a recommendation to be included in the guideline, consensus on the recommendation, including grading (class of recommendation, level of evidence), was required and defined as a two-thirds majority. Voting was done electronically by email for recommendations for which there was not consensus.

\section{Stakeholder input}

Although the guideline panel did not include any patient representatives, a final draft version of the guideline was circulated by email for comment to the entire membership of the Canadian Association for the Study of the Liver and community organizations that represented patients. Substantive comments were received from nine association members, including physicians and allied health workers. The guideline panel reviewed all com- ments received and made revisions to the guideline after discussion; a two-thirds majority agreement was required for a change to be incorporated. The executive of the Canadian Association for the Study of the Liver reviewed and approved this final version.

\section{Management of competing interests}

Members of the guideline panel have financial relationships with pharmaceutical companies related to HCV therapeutics. All members signed a commitment and competing interest statement at the outset of guideline development. Individuals with relevant disclosures were not excluded from voting on recommendations. However, in order to manage competing interests, the final guideline was vetted by the Canadian Association for the Study of the Liver membership, and specifically by the association's executive, to evaluate the presence of commercial bias. No funding, direct or in kind, was provided to the guideline panel for this work.

\section{Recommendations}

This abridged document summarizes key recommendations for practice and supporting evidence, which is expanded upon in the full guideline (available in Appendix 1, www.cmaj.ca/lookup/ suppl/doi:10.1503/cmaj.170453/-/DC1).

\section{Screening and linkage to care}

To increase the identification of the large proportion of persons living with undiagnosed $\mathrm{HCV}$, we recommend that screening be both

\section{Box 1: Grading system for recommendations ${ }^{20}$}

\begin{tabular}{|c|c|}
\hline Classification & Description \\
\hline \multicolumn{2}{|c|}{ Class of evidence } \\
\hline Class 1 & $\begin{array}{l}\text { Conditions for which there is evidence or } \\
\text { general agreement that a given diagnostic } \\
\text { evaluation procedure or treatment is beneficial, } \\
\text { useful and effective. }\end{array}$ \\
\hline Class 2 & $\begin{array}{l}\text { Conditions for which there is conflicting } \\
\text { evidence or a divergence of opinion about the } \\
\text { usefulness or efficacy of a diagnostic evaluation, } \\
\text { procedure or treatment. }\end{array}$ \\
\hline Class 2a & $\begin{array}{l}\text { Weight of evidence or opinion is in favour of } \\
\text { usefulness or efficacy. }\end{array}$ \\
\hline Class $2 \mathrm{~b}$ & $\begin{array}{l}\text { Usefulness or efficacy is less well established by } \\
\text { evidence or opinion. }\end{array}$ \\
\hline Class 3 & $\begin{array}{l}\text { Conditions for which there is evidence or } \\
\text { general agreement that a diagnostic evaluation, } \\
\text { procedure or treatment is not useful or effective } \\
\text { and in some cases may be harmful. }\end{array}$ \\
\hline \multicolumn{2}{|c|}{ Grade of evidence } \\
\hline Level A & $\begin{array}{l}\text { Data derived from multiple randomized clinical } \\
\text { trials or meta-analyses. }\end{array}$ \\
\hline Level B & $\begin{array}{l}\text { Data derived from a single randomized trial, or } \\
\text { nonrandomized studies. }\end{array}$ \\
\hline Level C & $\begin{array}{l}\text { Only consensus opinions of experts, case } \\
\text { studies, or standard of care. }\end{array}$ \\
\hline
\end{tabular}


risk-based and target the birth cohort of individuals born from 1945 to 1975, which currently encompasses the majority of persons chronically infected with HCV in Canada (class of recommendation: 2a; level of evidence: C).

A high proportion of Canadians with chronic HCV infection remain undiagnosed, with credible estimates ranging from $44 \%$ to $70 \%{ }^{4,23}$ The asymptomatic nature and slow progression of the infection require that individuals be identified through screening. Individuals at increased risk of infection should be tested for HCV (Box 2). In addition, based on a high prevalence and low testing rate among baby boomers, a strategy of one-time screening of all individuals born between 1945 and 1975 has been shown to be cost-effective and should be implemented in Canada. ${ }^{25}$

We recommend that anti-HCV antibody testing be the diagnostic test of choice for initial screening. If positive, a confirmatory HCV RNA polymerase chain reaction test is required to confirm chronic infection. In those with previous spontaneous or treatment-induced clearance and those with suspected acute infection, HCV RNA is the screening test of choice because anti-HCV antibody tests remain positive for life, even after spontaneous or treatment-induced clearance of HCV (class of recommendation: 1; level of evidence: $A$ ).

Initial screening should test for HCV antibodies (anti-HCV) with confirmation of active infection with HCV RNA in those who test antibody positive. ${ }^{26,27}$ Some individuals (15\%-30\%) may spontaneously clear infection shortly after acquisition, with no long-term consequences. Such individuals will test positive for anti-HCV antibodies but negative for HCV RNA; ${ }^{28}$ notably, they are not protected from reinfection. Once chronic (beyond six months), spontaneous clearance of HCV is extremely uncommon. ${ }^{28}$

We suggest that all individuals who test positive for HCV RNA be evaluated by practitioners with experience in HCV management (class of recommendation: 1; level of evidence: $\mathrm{C}$ ).

Despite a diagnosis of chronic hepatitis $C$, many patients are never seen by HCV experts, leading to low rates of treatment uptake and screening for complications. ${ }^{29}$ Training primary care providers, addiction specialists, nurses and nurse practitioners to provide HCV care, as well as using telemedicine approaches (e.g., Project ECHO) to co-manage patients, can lead to delivery of high-quality HCV treatment with outcomes similar to those achieved in academic centres. ${ }^{30,31}$ Expansion of nonspecialist $\mathrm{HCV}$ care will be required in Canada to ensure that all infected individuals receive appropriate care.

\section{Treatment}

All patients with chronic HCV infection should be considered candidates for antiviral therapy (class of recommendation: 1; level of evidence: $A)$.

The landscape of antiviral treatment for hepatitis $C$ is changing rapidly. With the markedly improved efficacy and safety of current therapy based on direct-acting antiviral agents and the well-documented benefits of achieving sustained virologic response, there is no longer any medical justification to restrict therapy, except in individuals with severe comorbidities and short life expectancy unrelated to HCV infection. As such, all indi- viduals with chronic HCV infection should be considered candidates for antiviral therapy. ${ }^{32}$

Prompt initiation of treatment should occur in certain patient subgroups, especially those with advanced liver fibrosis (F3 [bridging fibrosis] or F4 [cirrhosis], according to the Meta-analysis of Histological Data in Viral Hepatitis [METAVIR] classification), ${ }^{33}$ and those with extrahepatic manifestations of HCV infection. ${ }^{34}$

Patients with mild fibrosis (F0-F2) should also be considered for treatment. Viral eradication in this group improves healthrelated quality of life $e^{8,9}$ and may prevent incident infections in those at risk of infecting others (e.g., people engaged in highrisk activities). ${ }^{35}$

Notably, a careful review by the Canadian Agency for Drugs and Technologies in Health (CADTH) showed that treatment of HCV with interferon-free direct-acting antiviral agent-based therapy is cost-effective at all stages of fibrosis. ${ }^{36}$ Recent negotiated price reductions should make treatment more cost-effective (through the pan-Canadian Pharmaceutical Alliance). Although some regions in Canada continue to limit access to treatment to those with hepatic fibrosis, there is no medical or epidemiological evidence to support restrictions based on fibrosis stage. ${ }^{32,37-40}$ Price reductions have led to removal of restrictions in many jurisdictions.

\section{Pretreatment evaluation}

Initial evaluation should include questions about risk factors for viral acquisition to determine risks for transmission and estimate

Box 2: Populations for whom testing for hepatitis C virus (HCV) is recommended

\section{Risk factor-based screening ${ }^{24}$}

- History of current or past (even once) injection drug use*

- Received health care or personal services where there is a lack of infection prevention and control practices

- Received a blood transfusion, blood products or organ transplant before 1992 in Canada

- History of or current incarceration

- Born or resided in a region where hepatitis C prevalence is $>3 \%$, such as:

- Central, East and South Asia;

- Australasia and Oceania;

- Eastern Europe;

- Subsaharan Africa;

- North Africa or Middle East

- Born to a mother who is HCV-infected

- History of sexual contact or sharing of personal care items with someone who is HCV-infected*

- HIV infection, particularly men who have sex with men*

- Received chronic hemodialysis treatment

- Elevated alanine aminotransferase

Population-based screening ${ }^{25}$

- Born between the years 1945 and 1975

${ }^{*}$ Retesting should be performed at least once per year in those individuals who are engaged in ongoing high-risk activities and must be done with HCV RNA, as anti$\mathrm{HCV}$ will remain positive even after achievement of sustained virologic response. 
duration of infection, signs and symptoms of advanced liver disease or extrahepatic manifestations of chronic hepatitis C (e.g., rash, renal disease) and the presence of cofactors that may accelerate disease progression (e.g., alcohol, obesity, coinfections). Necessary laboratory testing includes virologic tests to confirm and characterize the infection (HCV RNA viral load, HCV genotype), liver biochemistry and function, abdominal ultrasound, an assessment of fibrosis stage and tests to rule out coinfections, such as hepatitis B virus and HIV (see Table 1 and Supplemental Table $2 b$ in Appendix 1 for more information).

Determination of HCV RNA, genotype and subtype (i.e., 1a v. 1b) is helpful in the management of patients with chronic HCV infection (class of recommendation: 1; level of evidence: $A$ ).

Documentation of viremia (detectable HCV RNA) is required to confirm active HCV infection. Some treatment regimens vary, depending on the level of HCV RNA; however, for most regimens, the HCV RNA level does not influence therapeutic decisionmaking. ${ }^{41}$ New regimens are effective against all HCV genotypes, and thus genotyping is not absolutely required before therapy if a pan-genotypic regimen is used, particularly in patients who do not have cirrhosis. ${ }^{42-46}$ However, many regimens are genotypeand/or subtype-specific, and even with pan-genotypic regimens, efficacy varies by genotype, which may be relevant for patients and providers to know before starting therapy. ${ }^{43,46}$ As such, genotyping before starting therapy is still recommended.

Liver fibrosis assessment to identify or exclude advanced fibrosis or cirrhosis is essential to the management of patients with chronic HCV infection (class of recommendation: 1; level of evidence: A).

An assessment of liver fibrosis is essential in all infected individuals. Identifying patients with cirrhosis is particularly important because of their increased risk of hepatic complications, lower treatment response and requirement for hepatocellular carcinoma surveillance, even after achievement of sustained virologic response. ${ }^{12,47,48}$ In those without overt evidence of cirrhosis on history or exam (e.g., ascites, encephalopathy) or routine tests (e.g., nodular shrunken liver or splenomegaly on ultrasound), an additional dedicated fibrosis assessment is required. Notably, absence of clinical signs or symptoms and even normal radiological findings do not adequately rule out cirrhosis. $^{21}$

Numerous noninvasive alternatives to liver biopsy have been developed, ${ }^{49}$ including serum markers (e.g., the Aspartate Aminotransferase to Platelet Ratio Index [APRI], ${ }^{50}$ FIB-4, FibroTest ${ }^{51}$ ), transient elastography (FibroScan, Echosens, Paris, France ${ }^{52-55}$ ) and other imaging-based tools. These tests are highly accurate for ruling out cirrhosis, the most important and clinically relevant issue. ${ }^{56}$ However, practitioners should be aware of the caveats associated with noninvasive approaches to fibrosis staging to allow for correct interpretation.

\section{Direct-acting antiviral agents}

Given the efficacy and markedly improved safety and tolerability of interferon-free direct-acting antiviral agent regimens, regimens containing pegylated interferon- $\alpha$ are no longer recommended for patients with HCV infection (class of recommendation 3; level of evidence: $A)$.

Multiple steps in the HCV life cycle have proven attractive targets for novel pharmacologic therapies (Appendix 1, Supplemental Figure 1). Agents that target the nonstructural 3/4A (NS3/4A) serine protease (-previr), the NS5B RNA-dependent RNA polymerase (-buvir) and the NS5A protein (-asvir) have been developed and approved for clinical use. ${ }^{57}$ Although initial approvals of direct-acting antiviral agents involved regimens administered in combination with pegylated interferon- $\alpha$, approvals since 2014 have been exclusively for interferon-free treatment regimens. Given the markedly improved efficacy, tolerability and safety of regimens that combine various direct-acting antiviral agents compared with regimens containing interferon, all patients would benefit from interferon-free therapy. ${ }^{42,46,58,59}$ Therefore, interferon-free regimens are recommended as firstline therapy for all indications.

Different classes of direct-acting antiviral agents have been combined to overcome drug resistance. However, substitutions in the viral sequence that are associated with resistance to antivirals (resistance-associated substitutions), particularly to NS5A inhibitors, may be present in some patients even before they receive therapy. For patients with genotype 1a and genotype 3 infections, the presence of baseline resistance may affect treatment choices, and we suggest testing in certain circumstances (see Appendix 1 for more details). For patients with other genotypes, the importance of resistance-associated substitutions is less clear and we do not recommend baseline testing.

Before beginning any direct-acting antiviral agent, potential drug-drug interactions must be considered, including those attributable to prescription and over-the-counter and herbal preparations. We suggest referring to an online updated database of drug-drug interactions before starting therapy (e.g., www.hep-druginteractions.org).

\section{Treatment regimens}

The suggested work-up before beginning HCV therapy is outlined in Table 1, with approved direct-acting antiviral agents HCV regimens in Canada listed in Table 2. Table 3 outlines treatment recommendations for people who have never received previous HCV treatment (treatment-naive) without cirrhosis. Regimens are recommended by HCV genotype, with the duration in weeks indicated. Treatment recommendations for people who have never received HCV treatment (treatmentnaive) with compensated cirrhosis are similarly outlined in Table 4. Recommendations for people who have been treated previously and for those with specific comorbidities (i.e., chronic kidney disease, decompensated cirrhosis, post-liver transplantation, hepatitis $B$ coinfection, injection drug use and others) are available in Appendix 1.

For all recommendations, the primary criteria for selecting a recommended regimen were antiviral efficacy (rate of sustained virologic response) and safety in phase III trials. Although some regimens may require longer duration of therapy, have more drug interactions, additional adverse effects or a higher pill burden, or require the use of ribavirin, such regimens were still listed 
as "recommended" if robust data demonstrated high efficacy and safety. For regimens in which resistance testing is recommended, strategies for patients with and without detectable resistance-associated substitutions are listed.
For each HCV genotype, multiple approved regimens are available. The comprehensive efficacy and safety data supporting the recommendation of each regimen for each population are provided in Appendix 1.

\section{Table 1: Suggested work-up before beginning HCV therapy}

\begin{tabular}{|c|c|c|}
\hline Category & Investigation & Considerations \\
\hline Routine bloodwork & $\begin{array}{l}\text { - Complete blood count } \\
\text { - Liver enzymes (alanine transaminase, aspartate } \\
\text { transaminase, alkaline phosphatase) } \\
\text { - Liver function (bilirubin, INR, albumin) } \\
\text { - Creatinine }\end{array}$ & $\begin{array}{l}\text { - Low platelets and elevated bilirubin or INR are } \\
\text { suggestive of cirrhosis } \\
\text { - Renal function is important to determine safety of } \\
\text { some regimens }\end{array}$ \\
\hline $\begin{array}{l}\text { Serology to exclude other } \\
\text { infections }\end{array}$ & $\begin{array}{l}\text { - HIV } \\
\text { - Hepatitis B (HBsAg, anti-HBs, anti-HBc) }\end{array}$ & $\begin{array}{l}\text { - If HIV-positive, treatment for HIV must take drug } \\
\text { interactions into consideration } \\
\text { - If HBsAg-positive or anti-HBc-positive, see section } \\
\text { on HBV coinfection (risk of HBV reactivation) } \\
\text { (Appendix 1) }\end{array}$ \\
\hline $\begin{array}{l}\text { Serology to exclude other } \\
\text { common liver diseases }\end{array}$ & $\begin{array}{l}\text { - Transferrin saturation (hemochromatosis) } \\
\text { - IgG }\end{array}$ & $\begin{array}{l}\text { - Elevated immunoglobulin } \mathrm{G} \text { may reflect cirrhosis or } \\
\text { possibly autoimmune hepatitis }\end{array}$ \\
\hline Staging of liver disease & $\begin{array}{l}\text { - } \text { APRI }^{\star} \\
\text { - FibroTest (serum panel) } \dagger \\
\text { - Ultrasound } \\
\text { - Transient elastography } \dagger\end{array}$ & $\begin{array}{l}\text { - All persons with HCV must have evaluation of } \\
\text { fibrosis to exclude cirrhosis. } \\
\text { - Normal ultrasound does not exclude cirrhosis. }{ }^{21} \\
\text { - APRI <0.7 has a very high negative predictive value } \\
\text { to exclude cirrhosis }{ }^{22}\end{array}$ \\
\hline HCV-specific & $\begin{array}{l}\text { - HCV genotype and HCV RNA } \\
\text { - Resistance testing (may be useful in select } \\
\text { circumstances) }\end{array}$ & $\begin{array}{l}\text { - To select appropriate regimen, and consideration } \\
\text { for addition of ribavirin. }\end{array}$ \\
\hline
\end{tabular}

Note: anti-HBC = hepatitis B core antibody, anti-HBs = hepatitis B surface antibody, APRI = Aspartate Aminotransferase to Patelet Ratio Index, $\mathrm{HBsAg}=$ hepatitis B virus surface antigen, $\mathrm{HBV}=$ hepatitis $\mathrm{B}$ virus, $\mathrm{HCV}=$ hepatitis $\mathrm{C}$ virus, $\mathrm{HIV}=$ human immunodeficiency virus, IgG = immunoglobulin $\mathrm{G}$, INR = international normalized ratio. *All persons with $\mathrm{HCV}$ should have a baseline ultrasound and evaluation of fibrosis.

tWhere available, use noninvasive technologies (e.g., transient elastography [Flbroscan], shear-wave elastography, MR-Elastography, or FibroTest).

\section{Table 2: Health Canada-approved direct-acting antiviral regimens in Canada}

\begin{tabular}{|c|c|c|c|c|}
\hline Regimen & Genotype & Pills per day & Duration (wk) & Comments \\
\hline \multicolumn{5}{|c|}{ Genotype-specific treatment regimens } \\
\hline $\begin{array}{l}\text { Elbasvir/grazoprevir } \\
\text { (Zepatier) }\end{array}$ & $1 \mathrm{a}, 1 \mathrm{~b}, 4$ & 1 & $12-16$ & $\begin{array}{l}\text { Resistance testing } \\
\text { recommended before } \\
\text { use in genotype 1a }\end{array}$ \\
\hline $\begin{array}{l}\text { Ledipasvir/sofosbuvir } \\
\text { (Harvoni) }\end{array}$ & $1 a, 1 b, 4,5,6$ & 1 & $8-24$ & \\
\hline $\begin{array}{l}\text { Paritaprevir/ritonavir/ombitasvir + } \\
\text { dasabuvir } \\
\text { (Holkira Pak) }\end{array}$ & $1,1 \mathrm{~b}$ & 4 & $8-24$ & $\begin{array}{l}\text { Ribavirin must be } \\
\text { added for genotype 1a }\end{array}$ \\
\hline $\begin{array}{l}\text { Paritaprevir/ritonavir/ombitasvir } \\
\text { (Technivie) }\end{array}$ & 4 & 2 & 12 & $\begin{array}{l}\text { Ribavirin must be } \\
\text { added }\end{array}$ \\
\hline $\begin{array}{l}\text { Sofosbuvir + daclatasvir } \\
\text { (Sovaldi + Daklinza) }\end{array}$ & $1 \mathrm{a}, 1 \mathrm{~b}, 3$ & 2 & $12-24$ & \\
\hline \multicolumn{5}{|l|}{ Pan-genotypic regimens } \\
\hline $\begin{array}{l}\text { Glecaprevir/pibrentasvir } \\
\text { (Maviret) }\end{array}$ & $1-6$ & 3 & $8-16$ & \\
\hline $\begin{array}{l}\text { Sofosbuvir/velpatasvir } \\
\text { (Epclusa) }\end{array}$ & $1-6$ & 1 & 12 & \\
\hline $\begin{array}{l}\text { Sofosbuvir/velpatasvir/ } \\
\text { voxilaprevir (Vosevi) }\end{array}$ & $1-6$ & 1 & 12 & $\begin{array}{l}\text { Approved only for } \\
\text { direct-acting antiviral } \\
\text { agent failures }\end{array}$ \\
\hline
\end{tabular}


Table 3: Recommended regimens and durations (weeks) for patients without cirrhosis who have never been treated, according to HCV genotype*

HCV genotype

\begin{tabular}{|c|c|c|c|c|c|c|c|}
\hline Regimen & $1 a$ & 1b & 2 & 3 & 4 & 5 & 6 \\
\hline $\begin{array}{l}\text { Ledipasvir/sofosbuvir } \\
\text { (Harvoni) }\end{array}$ & 8-12 wk† & $8-12 w k \dagger$ & NR & $\begin{array}{c}+ \text { ribavirin } \\
12 \mathrm{wk}\end{array}$ & 12 wk & 12 wk & $12 \mathrm{wk}$ \\
\hline $\begin{array}{l}\text { Elbasvir/grazoprevir } \\
\text { (Zepatier) }\end{array}$ & $\begin{array}{l}12-16 \text { wk } \\
\pm \text { ribavirin } \ddagger\end{array}$ & $8-12$ wk§ & NR & $\begin{array}{l}+ \text { sofosbuvir } \\
\text { x } 12 \text { wk }\end{array}$ & 12 wk & NR & NR \\
\hline $\begin{array}{l}\text { Paritaprevir/ritonavir/ombitasvir } \\
+ \text { dasabuvir } \\
\text { (Holkira Pak) }\end{array}$ & $\begin{array}{c}+ \text { ribavirin } \\
12 \mathrm{wk}\end{array}$ & 12 wk & NR & NR & $\begin{array}{c}\text { Paritaprevir/ } \\
\text { ritonavir/ } \\
\text { ombitasvir + } \\
\text { ribavirin } 12 \text { wk }\end{array}$ & NR & NR \\
\hline $\begin{array}{l}\text { Sofosbuvir + daclatasvir } \\
\text { (Sovaldi + Daklinza) }\end{array}$ & $12 w k$ & $12 \mathrm{wk}$ & $12 w k$ & 12 wk & NR & NR & NR \\
\hline $\begin{array}{l}\text { Sofosbuvir/velpatasvir } \\
\text { (Epclusa) }\end{array}$ & $12 w k$ & 12 wk & 12 wk & 12 wk & 12 wk & 12 wk & $12 \mathrm{wk}$ \\
\hline $\begin{array}{l}\text { Glecaprevir/pibrentasvir } \\
\text { (Maviret) }\end{array}$ & $8 w k$ & $8 w k$ & $8 w k$ & $8 w k$ & $8 w k$ & $8 w k$ & $8 w k$ \\
\hline $\begin{array}{l}\text { Sofosbuvir/velpatasvir/ } \\
\text { voxilarevir (Vosevi)ฯ }\end{array}$ & NR & NR & NR & NR & NR & NR & NR \\
\hline
\end{tabular}

Note: $\mathrm{HCV}=$ hepatitis $\mathrm{C}$ virus, $\mathrm{HIV}=$ human immunodeficiency virus, $\mathrm{NR}=$ not recommended.

*Where indicated, to be dosed according to weight: $\leq 75 \mathrm{~kg}: 1000 \mathrm{mg}$ daily; $\geq 75 \mathrm{~kg}: 1200 \mathrm{mg}$ daily. See Appendix 1 for reference supporting recommendations.

$\dagger$ In individuals without cirrhosis and without HIV with a viral load $<6$ million IU/mL, an 8-week regimen of ledipasvir/sofosbuvir may be considered.

$\ddagger$ Resistance testing suggested for people with genotype 1a infection before treatment with elbasvir/grazoprevir. If resistance to nonstructural $5 \mathrm{~A}$ (NS5A) inhibitors is present, treatment should be extended to 16 weeks with the addition of weight-based ribavirin.

§Eight weeks recommended in treatment-naive patients with fibrosis stages F0-F2. For those with F3 or F4, 12 weeks of therapy should be given.

IReserved for individuals who have been treated previously with direct-acting antiviral agents.

Table 4: Recommended regimens and durations (weeks) for patients with compensated cirrhosis who have never been treated, according to HCV genotype*

\begin{tabular}{|c|c|c|c|c|c|c|c|}
\hline \multirow[b]{2}{*}{ Regimen } & \multicolumn{7}{|c|}{ HCV genotype } \\
\hline & $1 \mathbf{a}$ & 1b & 2 & 3 & 4 & 5 & 6 \\
\hline $\begin{array}{l}\text { Ledipasvir/sofosbuvir } \\
\text { (Harvoni) }\end{array}$ & $\begin{array}{l}12 \mathrm{wk} \pm \\
\text { ribavirint }\end{array}$ & 12 wk & NR & $\begin{array}{c}+ \text { ribavirin } \\
12 \mathrm{wk}\end{array}$ & $12 w k$ & 12 wk & 12 wk \\
\hline $\begin{array}{l}\text { Elbasvir/grazoprevir } \\
\text { (Zepatier) }\end{array}$ & $\begin{array}{l}12-16 \text { wk } \\
\pm \text { ribavirint }\end{array}$ & $12 w k$ & NR & $\begin{array}{c}+ \text { sofosbuvir } \\
\text { x } 12 \text { wk }\end{array}$ & 12 wk & NR & NR \\
\hline $\begin{array}{l}\text { Paritaprevir/ritonavir/ombitasvir } \\
\text { + dasabuvir } \\
\text { (Holkira Pak) }\end{array}$ & $\begin{array}{l}+\mathrm{RBV} \\
12 \mathrm{wk}\end{array}$ & 12 wk & NR & NR & $\begin{array}{c}\text { Paritaprevir/ } \\
\text { ritonavir/ } \\
\text { ombitasvir + } \\
\text { ribavirin } 12 \text { wk }\end{array}$ & NR & NR \\
\hline $\begin{array}{l}\text { Sofosbuvir + daclatasvir } \\
\text { (Sovaldi + Daklinza) }\end{array}$ & 24 wk & $24 w k$ & $24 w k$ & $\begin{aligned} & 24 \text { wk } \\
\pm & \text { ribavirin }\end{aligned}$ & NR & NR & NR \\
\hline $\begin{array}{l}\text { Sofosbuvir/velpatasvir } \\
\text { (Epclusa) }\end{array}$ & 12 wk & 12 wk & $12 w k$ & $\begin{array}{l}12 \mathrm{wk} \pm \\
\text { ribavirin } \ddagger\end{array}$ & $12 w k$ & $12 w k$ & 12 wk \\
\hline $\begin{array}{l}\text { Glecaprevir/pibrentasvir } \\
\text { (Maviret) }\end{array}$ & 12 wk & 12 wk & $12 w k$ & 12 wk & $12 w k$ & $12 w k$ & $12 w k$ \\
\hline $\begin{array}{l}\text { Sofosbuvir/velpatasvir/ } \\
\text { voxilaprevir (Vosevi) }\end{array}$ & NR & NR & NR & NR & NR & NR & NR \\
\hline $\begin{array}{l}\text { Note: } \mathrm{HCV}=\text { hepatitis } \mathrm{C} \text { virus, NR = not rec } \\
\text { *Where indicated, to be dosed according } \\
\text { †Resistance testing suggested for people } \\
\text { nonstructural } 5 \mathrm{~A} \text { (NS5A) inhibitors is pres } \\
\text { †Resistance testing suggested for people } \\
\text { addition of weight-based ribavirin may be }\end{array}$ & $\begin{array}{l}\text { nended, RBV = r } \\
\text { eight: } \leq 75 \mathrm{~kg}: 1 \\
\text { genotype } 1 \mathrm{a} \text { in } \\
\text { treatment shou } \\
\text { genotype } 3 \text { infe } \\
\text { isidered. }\end{array}$ & $\begin{array}{l}\text { n. } \\
\text { daily; } \geq 7 \\
\text { with com } \\
\text { xtended } t \\
\text { with comp }\end{array}$ & $\begin{array}{l}\text { mg daily } \\
\text { cirrhosis } \\
\text { k with the } \\
\text { cirrhosis b }\end{array}$ & $\begin{array}{l}\text { ppendix } 1 \text { for refe } \\
\text { treatment with l } \\
\text { ion of weight-bas } \\
\text { treatment with so }\end{array}$ & $\begin{array}{l}\text { ce supporting recon } \\
\text { pasvir/sofosbuvir or } \\
\text { ribavirin. } \\
\text { buvir/velpatasvir. If } r\end{array}$ & $\begin{array}{l}\text { ations. } \\
\text { r/grazopr } \\
\text { ce to NS5 }\end{array}$ & $\begin{array}{l}\text { stance to } \\
\text { rs is present, }\end{array}$ \\
\hline
\end{tabular}


Genotype 1: Genotype 1 is the most prevalent HCV genotype in Canada and most patients are infected with either genotype $1 \mathrm{a}$ or $1 \mathrm{~b} .{ }^{60}$ Subtyping is important because some regimens are more effective against genotype $1 \mathrm{~b}$ than $1 \mathrm{a} .{ }^{61}$ Treatment recommendations for treatment-naive patients without cirrhosis (Table 3) and with compensated cirrhosis (Table 4) are listed by genotype and subtype. Baseline resistance testing is recommended in clinical situations for which outcomes differ and alternative treatment strategies exist.

Genotype 2: Although high sustained virologic response rates were achieved with interferon-based therapy for genotype 2 infection, the improved tolerability, shorter course and improved sustained virologic response rates with interferon-free regimens justify their use. ${ }^{43,44,62}$ Treatment recommendations are presented for patients who are treatment-naive without cirrhosis (Table 3) or with compensated cirrhosis (Table 4).

Genotype 3: Genotype 3 infection is associated with more aggressive natural history, faster progression to cirrhosis and higher rates of hepatocellular carcinoma than other HCV genotypes. ${ }^{63}$ Patients with HCV genotype 3 and cirrhosis have lower sustained virologic response rates than other populations treated with direct-acting antiviral agents. ${ }^{43}$ Treatment recommendations are presented for patients who are treatment-naive without cirrhosis (Table 3) or with compensated cirrhosis (Table 4).

Genotypes 4, 5, 6: Genotype 4 is very diverse, with multiple subtypes; however, to date no clear difference in response has been observed by subtype. Studies of genotype 5 and genotype 6 are limited because of the low prevalence of these patients with these HCV genotypes in Europe and North America. Treatment recommendations are presented for patients who are treatmentnaive without cirrhosis (Table 3 ) or with compensated cirrhosis (Table 4).

\section{Decompensated cirrhosis and post-liver transplantation:} Decompensated cirrhosis refers to present or history of ascites, esophageal variceal hemorrhage, jaundice or hepatic encephalopathy. Patients with decompensated cirrhosis have a high risk of morbidity and short-term liver-related mortality and thus should be treated in centres experienced in managing end-stage liver disease. Notably, all protease inhibitors (grazoprevir, glecaprevir, paritaprevir, voxilaprevir, simeprevir) are contraindicated in patients with decompensated cirrhosis, because these drugs are hepatically metabolized and may accumulate to very high and toxic levels in patients with impaired hepatic function. ${ }^{64}$ Although regimens that are not based on protease inhibitors appear safe, instances of hepatotoxicity or worsening decompensation during treatment have been reported. ${ }^{65}$ The benefits of antiviral therapy must be carefully weighed against the risks of on-treatment complications and the prospect of limited improvement with sustained virologic response in patients with decompensated cirrhosis. No firm criteria have been established to identify patients who should defer treatment until after transplantation. However, we suggest that patients with Model for
End-stage Liver Disease (MELD) scores above 15 to 18 may benefit from deferral of therapy. ${ }^{66-70}$ Patients with decompensated cirrhosis should be evaluated in centres that have experience with end-stage liver disease because of the risk of worsening decompensation during therapy. Specific recommendations for treatment of decompensated cirrhosis are presented in Appendix 1. Results of treatment after liver transplantation are similar to those in the nontransplant setting (Appendix 1). However, drugdrug interactions must be carefully considered in all patients.

\section{Posttreatment follow-up}

Patients who achieve sustained virologic response and do not have cirrhosis require no specific liver-related follow-up. In those with ongoing risk exposures, annual HCV RNA testing to assess for reinfection is suggested (class of recommendation: 1; level of evidence: $B$ ).

For patients without cirrhosis who achieve sustained virologic response, no specific follow-up is required. Patients will remain anti-HCV antibody-positive for life, but are not protected from reinfection. ${ }^{71}$ The risk of late relapse is extremely low ${ }^{72,73}$ and repeat HCV RNA testing is warranted only in those with unexplained alanine aminotransferase elevation or with ongoing risk exposures (e.g., people who inject drugs), in whom annual HCV RNA testing should be considered. Individuals who are reinfected should be managed in the same way as anyone with primary $\mathrm{HCV}$, with a continued strong emphasis on harm reduction practices. ${ }^{74}$

Patients who achieve sustained virologic response and have cirrhosis require ongoing screening for hepatocellular carcinoma indefinitely (class of recommendation: 1; level of evidence: $B$ ).

For patients who have cirrhosis before the start of therapy, ongoing follow-up is required. Surveillance for hepatocellular carcinoma with biannual ultrasound should be continued indefinitely after sustained virologic response is achieved, even if noninvasive tests no longer suggest the presence of cirrhosis. ${ }^{75-79}$ For those with a treated hepatocellular carcinoma before sustained virologic response, close surveillance is required after HCV treatment, with some reports suggesting an increased risk of recurrence of hepatocellular carcinoma after viral clearance..$^{80,81}$

Patients who do not achieve sustained virologic response should be considered for retreatment with a salvage regimen (class of recommendation: 1; level of evidence: $A$ ).

For patients who do not achieve sustained virologic response, issues such as adherence and drug-drug interactions should be discussed and retreatment should be considered. Salvage regimens have recently been approved that have high efficacy and similar safety to other direct-acting antiviral agent regimens. The fixed-dose combination single-tablet regimen of sofosbuvir/ velpatasvir/voxilaprevir for 12 weeks is effective against all HCV genotypes with sustained virologic response rates above $95 \%$ in patients who did not achieve sustained virologic response after a course of first-line antiviral therapy based on direct-acting antiviral agents. ${ }^{82}$ Other salvage regimens, including the combination of glecaprevir/pibrentasvir, have been less well studied for retreatment. ${ }^{83}$ Details about retreatment are included in Appendix 1. 


\section{Implementation}

This synopsis and the full version of the guideline (Appendix 1) is posted on the Canadian Association for the Study of the Liver website (www.hepatology.ca/). In addition, a custom searchable website is being developed so practitioners can navigate directly to the patient profile of interest. This guideline will be presented to policymakers for integration into Canadian treatment funding models.

The impact of these guidelines on resource utilization is unknown. However, there is strong evidence demonstrating the cost-effectiveness of hepatitis $\mathrm{C}$ treatment for all patient subgroups at all levels of fibrosis. . $5,84,85$ Increased screening efforts and treatment uptake will be required to meet the World Health Organization targets for elimination of HCV as a public health problem by 2030 .

This document will be updated annually and revised versions of recommendations will be placed on the Canadian Association for the Study of the Liver website immediately.

\section{Other guidelines}

The treatment recommendations in this guideline update are markedly changed from the previous Canadian Association for the Study of the Liver treatment guidelines because of multiple advances in the field since their publication, including the development of pan-genotypic regimens, retreatment options after nonresponse to direct-acting antiviral agents and treatment options for populations with substantial medical comorbidities. ${ }^{16}$ The current recommendations are very similar to those of other recent guidelines from national and international societies, including the European Association for the Study of the Liver ${ }^{86}$ and the American Association for the Study of Liver Disease and Infectious Disease Society of America. ${ }^{87}$

The notable differences from these other societies' recommendations are greater use of resistance testing to guide therapy in our guideline and support for a broader list of recommended therapies in our guideline for some populations. The rationale for these differences is detailed in Appendix 1.

Briefly, new data have emerged to support the use of resistance testing for certain regimens and certain populations, and testing is readily available in Canada. The guideline panel chose to recommend regimens equally where the efficacy and safety data were similar and where they were supported by high-quality evidence without strong consideration of factors that may influence the choice of therapy for an individual patient (e.g., pill burden, drug interactions), but that do not affect overall efficacy or safety of the regimen. Importantly, regimen-specific factors may have a major influence for individuals considering therapy and should be discussed thoroughly by practitioners to help choose the preferred treatment option for a given individual.

The Canadian Task Force for Preventive Health recently published recommendations against screening individuals who are not at high risk of HCV infection. ${ }^{88}$ They did not recommend screening the Baby Boomer birth cohort (1945-1975). The guideline panel strongly disagreed with the task force recommendations and unanimously agreed that the current evidence supports one-time screening of the baby boomer birth cohort in Canada, which is in line with recommendations from other countries for birth cohort screening, most notably the United States ${ }^{89}$ and France. ${ }^{90}$ The rationale for the difference in screening recommendations is explained in greater detail in Appendix 1. Briefly, the panel felt that the task force overvalued the harms of screening, particularly the costs of therapy; undervalued the benefits of curative treatment; relied on outdated data on the costs of HCV therapy and HCV prevalence in Canada; and largely disregarded modelling and cost-effectiveness data supporting screening. We have advocated for screening of the baby boomer cohort for the following reasons: recent data show that the HCV prevalence is highest among the baby boomer birth cohort (1.55\%), accounting for an estimated $62.7 \%$ of all HCV infections in Canada, and the burden of liver disease is expected to increase markedly in this group; ${ }^{1,91}$ best estimates suggest that HCV infection remains undiagnosed in 45\%-70\% of Canadians infected with $\mathrm{HCV},{ }^{4,92}$ indicating that the longstanding policy of screening based on risk factors has been unsuccessful. Moreover, the pan-Canadian Pharmaceutical Alliance has recently negotiated markedly lower prices for HCV therapy, leading to broader access for those who have received a diagnosis of HCV infection, making a screen-and-treat strategy even more cost-effective than previous estimates ${ }^{25,93}$ and overcoming the concern of the task force that patients will be diagnosed without having access to therapy.

\section{Gaps in knowledge}

Despite substantial advances between 2010 and 2017 in efficacy, safety and tolerability of treatment, many gaps in knowledge remain. We are unable to cure every infected patient, and we currently have limited treatment options for patients with decompensated cirrhosis, particularly those who have failed an all-oral regimen. These patients represent the minority of individuals with HCV infection.

In the coming years, the major challenge of HCV management will not be treatment, but rather prevention, screening and linkage to care. Although many novel models of care have been developed, the optimal strategies, particularly to reach vulnerable populations, are not clear and must be a major research priority.

The efficacy, safety and simplicity of new HCV regimens mean that therapy no longer must be provided in specialty clinics, with recent data showing high efficacy and improved patient satisfaction when HCV is treated in primary care. ${ }^{31}$ To reach all infected Canadians, expansion of the pool of those providing treatment will need to be a major priority, particularly among primary care providers for populations with a high burden of HCV, such as those born in countries with high prevalence of HCV infection, Indigenous populations and those in addiction services, prisons and other high-prevalence settings.

Beyond treatment, addressing $\mathrm{HCV}$ in Canada will require coordination of services to address harm reduction and many of the social determinants of health that have an impact on the burden and course of HCV-related disease. The development of a 
coordinated National Action Plan to address HCV, as recommended by the World Health Organization, should be a priority to ensure that Canada is on track to meet the HCV elimination targets by $2030 . .^{94}$

\section{Conclusion}

The landscape for HCV treatment continues to change at a rapid pace. This guideline provides updated evidence-based recommendations for the treatment of patients with HCV infection.

\section{References}

1. Myers RP, Liu M, Shaheen AA. The burden of hepatitis C virus infection is growing: a Canadian population-based study of hospitalizations from 1994 to 2004. Can J Gastroenterol 2008;22:381-7.

2. Myers RP, Krajden M, Bilodeau M, et al. Burden of disease and cost of chronic hepatitis C infection in Canada. Can J Gastroenterol Hepatol 2014;28:243-50.

3. Schanzer DL, Paquette D, Lix LM. Historical trends and projected hospital admissions for chronic hepatitis $\mathrm{C}$ infection in Canada: a birth cohort analysis. CMAJ Open 2014;2:E139-44.

4. Rotermann M, Langlois K, Andonov A, et al. Seroprevalence of hepatitis B and $C$ virus infections: results from the 2007 to 2009 and 2009 to 2011 Canadian Health Measures Survey. Health Rep 2013;24:3-13.

5. Yoshida EM, Sulkowski MS, Gane EJ, et al. Concordance of sustained virological response 4,12 , and 24 weeks post-treatment with sofosbuvir-containing regimens for hepatitis C virus. Hepatology 2015;61:41-5.

6. Maylin S, Martinot-Peignoux M, Moucari R, et al. Eradication of hepatitis C virus in patients successfully treated for chronic hepatitis C. Gastroenterology 2008;135:821-9.

7. Swain MG, Lai MY, Shiffman ML, et al. A sustained virologic response is durable in patients with chronic hepatitis $C$ treated with peginterferon alfa-2a and ribavirin. Gastroenterology 2010;139:1593-601.

8. Myers RP, Cooper C, Sherman M, et al. Outcomes of chronic hepatitis C therapy in patients treated in community versus academic centres in Canada: final results of APPROACH (a prospective study of peginterferon alfa-2a and ribavirin at academic and community centres in Canada). Can J Gastroenterol 2011;25:503-10.

9. Neary MP, Cort S, Bayliss MS, et al. Sustained virologic response is associated with improved health-related quality of life in relapsed chronic hepatitis C patients. Semin Liver Dis 1999;19(Suppl 1):77-85

10. Poynard T, McHutchison J, Manns M, et al. Impact of pegylated interferon alfa$2 \mathrm{~b}$ and ribavirin on liver fibrosis in patients with chronic hepatitis C. Gastroenterology 2002;122:1303-13.

11. Poynard T, McHutchison J, Davis GL, et al. Impact of interferon alfa-2b and ribavirin on progression of liver fibrosis in patients with chronic hepatitis C. Hepatology 2000;32:1131-7.

12. van der Meer AJ, Veldt BJ, Feld JJ, et al. Association between sustained virological response and all-cause mortality among patients with chronic hepatitis C and advanced hepatic fibrosis. JAMA 2012;308:2584-93.

13. Veldt BJ, Heathcote EJ, Wedemeyer $\mathrm{H}$, et al. Sustained virologic response and clinical outcomes in patients with chronic hepatitis $C$ and advanced fibrosis. Ann Intern Med 2007;147:677-84.

14. Backus LI, Boothroyd DB, Phillips BR, et al. A sustained virologic response reduces risk of all-cause mortality in patients with hepatitis C. Clin Gastroenterol Hepatol 2011;9:509-516. e1.

15. Singal AG, Volk ML, Jensen $D$, et al. A sustained viral response is associated with reduced liver-related morbidity and mortality in patients with hepatitis C virus. Clin Gastroenterol Hepatol 2010;8(3):280-288, 288.e1.

16. Myers RP, Shah H, Burak KW, et al. An update on the management of chronic hepatitis C: 2015 Consensus guidelines from the Canadian Association for the Study of the Liver. Can J Gastroenterol Hepatol 2015;29:19-34.
17. Hull MSS, Shafran S, Wong A, et al. CIHR Canadian HIV Trials Network Coinfection and Concurrent Diseases Core Research Group: 2016 updated Canadian HIV/hepatitis C adult guidelines for management and treatment. Can J Infect Dis Med Microbiol 2016;2016:4385643. doi:10.1155/2016/4385643.

18. Shiffman RN, Shekelle P, Overhage JM, et al. Standardized reporting of clinical practice guidelines: a proposal from the Conference on Guideline Standardization. Ann Intern Med 2003;139:493-8.

19. Methodology Manual and Policies from the ACCF/AHA Task Force on Practice Guidelines [report]. American College of Cardiology Foundation and American Heart Association; 2010. Available: http://my.americanheart.org/idc/ groups/ahamah-public/@wcm/@sop/documents/downloadable/ucm_319826 .pdf (accessed 2017 Oct. 17).

20. Myers RP, Ramji A, Bilodeau M, et al. An update on the management of hepatitis C: consensus guidelines from the Canadian Association for the Study of the Liver. Can J Gastroenterol 2012;26:359-75.

21. Mathiesen UL, Franzén LE, Aselius H, et al. Increased liver echogenicity at ultrasound examination reflects degree of steatosis but not of fibrosis in asymptomatic patients with mild/moderate abnormalities of liver transaminases. Dig Liver Dis 2002;34:516-22.

22. Lin ZH, Xin YN, Dong QJ, et al. Performance of the aspartate aminotransferaseto-platelet ratio index for the staging of hepatitis C-related fibrosis: an updated meta-analysis. Hepatology 2011;53:726-36.

23. Trubnikov M, Yan P, Archibald C. Estimated prevalence of hepatitis C virus infection in Canada, 2011. Can Commun Dis Rep 2014;40:429-36.

24. Ha S, Totten S, Pogany L, et al. Hepatitis C in Canada and the importance of risk-based screening. Can Commun Dis Rep 2016;42:57-62.

25. Wong WW, Tu HA, Feld JJ, et al. Cost-effectiveness of screening for hepatitis C in Canada. CMAJ 2015;187:E110-21.

26. Testing for HCV infection: an update of guidance for clinicians and laboratorians. MMWR Morb Mortal Wkly Rep 2013;62:362-5.

27. Granados-García V, Contreras AM, García-Peña C, et al. Cost-effectiveness analysis of different testing strategies that use antibody levels to detect chronic hepatitis C in blood donors. PLoS One 2016;11:e0154625.

28. Bulteel N, Partha Sarathy P, Forrest E, et al. Factors associated with spontaneous clearance of chronic hepatitis C virus infection. J Hepatol 2016;65:266-72.

29. Janjua NZ, Kuo M, Yu A, et al. The population level cascade of care for hepatitis C in British Columbia, Canada: The BC Hepatitis Testers Cohort (BC-HTC). EBioMedicine 2016;12:189-95.

30. Arora S, Thornton K, Murata G, et al. Outcomes of treatment for hepatitis C virus infection by primary care providers. N Engl J Med 2011;364:2199-207.

31. Kattakuzhy S, Gross C, Emmanuel B, et al. Expansion of treatment for hepatitis $C$ virus infection by task shifting to community-based nonspecialist providers: a nonrandomized clinical trial. Ann Intern Med 2017;167:311-8.

32. Backus LI, Belperio PS, Shahoumian TA, et al. Direct-acting antiviral sustained virologic response: impact on mortality in patients without advanced liver disease. Hepatology 2018 Jan. 29 [Epub ahead of print] doi: 10.1002/hep.29811.

33. Bedossa P, Poynard T. An algorithm for the grading of activity in chronic hepatitis C. The METAVIR Cooperative Study Group. Hepatology 1996;24:289-93.

34. Emery JS, Kuczynski M, La D, et al. Efficacy and safety of direct acting antivirals for the treatment of mixed cryoglobulinemia. Am J Gastroenterol 2017;112:1298-308.

35. Hellard M, Rolls DA, Sacks-Davis R, et al. The impact of injecting networks on hepatitis $C$ transmission and treatment in people who inject drugs. Hepatology 2014;60:1861-70.

36. Murphy G, Farah B, Wong W, et al. 2014. Direct-acting antiviral agents for chronic hepatitis $\mathrm{C}$ genotype 1 [report]. Ottawa: Canadian Agency for Drugs and Technologies in Health; Oct. 3, 2014.

37. Barua S, Greenwald R, Grebely J, et al. Restrictions for Medicaid reimbursement of sofosbuvir for the treatment of hepatitis $C$ virus infection in the united states. Ann Intern Med 2015;163:215-23.

38. El-Kamary SS, Jhaveri R, Shardell MD. All-cause, liver-related, and non-liverrelated mortality among $\mathrm{HCV}$-infected individuals in the general US population. Clin Infect Dis 2011;53:150-7. 
39. Innes HA, McDonald SA, Dillon JF, et al. Toward a more complete understanding of the association between a hepatitis $C$ sustained viral response and causespecific outcomes. Hepatology 2015;62:355-64.

40. Marshall AD, Saeed S, Barrett L, et al. Restrictions for reimbursement of directacting antiviral treatment for hepatitis $C$ virus infection in Canada: a descriptive study. CMAJ Open 2016;4:E605-14.

41. Kowdley KV, Gordon SC, Reddy KR, et al. Ledipasvir and sofosbuvir for 8 or 12 weeks for chronic HCV without cirrhosis. N Engl J Med 2014;370:1879-88.

42. Feld JJ, Jacobson IM, Hézode C, et al. Sofosbuvir and velpatasvir for HCV genotype 1, 2, 4, 5, and 6 infection. N Engl J Med 2015;373:2599-607.

43. Foster GR, Afdhal N, Roberts SK, et al. Sofosbuvir and velpatasvir for HCV genotype 2 and 3 infection. N Engl J Med 2015;373:2608-17.

44. Asselah T, Kowdley KV, Zadeikis N, et al. Efficacy of glecaprevir/pibrentasvir for 8 or 12 weeks in patients with hepatitis $C$ virus genotype 2, 4, 5, or 6 infection without cirrhosis. Clin Gastroenterol Hepatol 2018;16:417-26.

45. Forns X, Lee SS, Valdes J, et al. Glecaprevir plus pibrentasvir for chronic hepatitis C virus genotype $1,2,4,5$, or 6 infection in adults with compensated cirrhosis (EXPEDITION-1): a single-arm, open-label, multicentre phase 3 trial. Lancet Infect Dis 2017;17:1062-8.

46. Zeuzem S, Foster GR, Wang S, et al. Glecaprevir-pibrentasvir for 8 or 12 weeks in HCV genotype 1 or 3 infection. N Engl J Med 2018;378:354-69.

47. Reddy KR, Lim JK, Kuo A, et al. All-oral direct-acting antiviral therapy in HCVadvanced liver disease is effective in real-world practice: observations through HCV-TARGET database. Aliment Pharmacol Ther 2017;45:115-26.

48. Kanwal F, Kramer J, Asch SM, et al. Risk of hepatocellular cancer in HCV patients treated with direct-acting antiviral agents. Gastroenterology 2017;153:996-1005.e1.

49. Guha IN, Myers RP, Patel K, et al. Biomarkers of liver fibrosis: what lies beneath the receiver operating characteristic curve? Hepatology 2011;54:1454-62.

50. Shaheen AA, Myers RP. Diagnostic accuracy of the aspartate aminotransferaseto-platelet ratio index for the prediction of hepatitis C-related fibrosis: a systematic review. Hepatology 2007;46:912-21.

51. Poynard T, Imbert-Bismut F, Munteanu M, et al. Overview of the diagnostic value of biochemical markers of liver fibrosis (FibroTest, HCV FibroSure) and necrosis (ActiTest) in patients with chronic hepatitis C. Comp Hepatol 2004;3:8

52. Friedrich-Rust M, Ong MF, Martens S, et al. Performance of transient elastography for the staging of liver fibrosis: a meta-analysis. Gastroenterology 2008; 134:960-74.

53. Myers RP, Elkashab M, Ma M, et al. Transient elastography for the noninvasive assessment of liver fibrosis: a multicentre Canadian study. Can J Gastroenterol 2010;24:661-70.

54. Myers RP, Pomier-Layrargues G, Kirsch R, et al. Feasibility and diagnostic performance of the FibroScan XL probe for liver stiffness measurement in overweight and obese patients. Hepatology 2012;55:199-208.

55. Castera L. Transient elastography and other noninvasive tests to assess hepatic fibrosis in patients with viral hepatitis. J Viral Hepat 2009;16:300-14

56. Kelly ML, Riordan SM, Bopage R, et al. Capacity of non-invasive hepatic fibrosis algorithms to replace transient elastography to exclude cirrhosis in people with hepatitis $C$ virus infection: a multi-centre observational study. PLoS One 2018;13:e0192763.

57. Kronenberger B, Zeuzem S. New developments in HCV therapy. J Viral Hepat 2012;19(Suppl 1):48-51.

58. Suwanthawornkul T, Anothaisintawee T, Sobhonslidsuk A, et al. Efficacy of second generation direct-acting antiviral agents for treatment naïve hepatitis $C$ genotype 1: a systematic review and network meta-analysis. PLoS One 2015;10:e0145953.

59. McHutchison JG, Lawitz EJ, Shiffman ML, et al. Peginterferon alfa-2b or alfa-2a with ribavirin for treatment of hepatitis C infection. N Engl J Med 2009;361:580-93.

60. Chaudhary R, Tepper M, Eisaadany S, et al. Distribution of hepatitis C virus genotypes in Canada: results from the LCDC Sentinel Health Unit Surveillance System. Can J Infect Dis 1999;10:53-6.
61. Sulkowski M, Hezode C, Gerstoft J, et al. Efficacy and safety of 8 weeks versus 12 weeks of treatment with grazoprevir (MK-5172) and elbasvir (MK-8742) with or without ribavirin in patients with hepatitis $C$ virus genotype 1 mono-infection and HIV/hepatitis C virus co-infection (C-WORTHY): a randomised, open-label phase 2 trial. Lancet 2015;385:1087-97.

62. Lawitz E, Mangia A, Wyles D, et al. Sofosbuvir for previously untreated chronic hepatitis C infection. N Engl J Med 2013;368:1878-87.

63. Kanwal F, Kramer JR, Ilyas J, et al. HCV genotype 3 is associated with an increased risk of cirrhosis and hepatocellular cancer in a national sample of US veterans with HCV. Hepatology 2014;60:98-105.

64. Chen T, Terrault N. Treatment of chronic hepatitis $C$ in patients with cirrhosis Curr Opin Gastroenterol 2016;32:143-51.

65. Dyson JK, Hutchinson J, Harrison L, et al. Liver toxicity associated with sofosbuvir, an NS5A inhibitor and ribavirin use. J Hepatol 2016;64:234-8.

66. Maan R, van Tilborg M, Deterding K, et al. Safety and effectiveness of directacting antiviral agents for treatment of patients with chronic hepatitis $C$ virus infection and cirrhosis. Clin Gastroenterol Hepatol 2016;14:1821-30.e6.

67. Fernández-Carrillo $\mathrm{C}$, Lens $\mathrm{S}$, Llop $\mathrm{E}$, et al. Treatment of hepatitis $\mathrm{C}$ virus in patients with advanced cirrhosis: Always justified? Analysis of the HEPA-C registry [abstract GS01]. Proceedings of the 51st Annual Meeting of the European Association for the Study of the Liver (EASL); 2016 Apr. 13-17; Barcelona, Spain.

68. Coilly A, Pageaux G-P, Houssel-Debry P, et al. Improving liver function and delisting of patients awaiting liver transplantation for HCV cirrhosis: do we ask too much to DAA? [abstract 95]. Proceedings of the 66th Annual Meeting of the American Association for the Study of Liver Diseases (AASLD); 2015 Nov. 13-17. San Francisco.

69. Belli L, Berenguer M, Rockenschaub S-R, et al. Impact of direct anti-viral agents on inactivation/de-listing of liver transplant candidates listed for decompensated c cirrhosis: a European study (PS036). Proceedings of the 51st Annual Meeting of the European Association for the Study of the Liver (EASL); 2016 Apr. 13-17; Barcelona, Spain.

70. Pascasio J, Vinaixa C, Ferrer M, et al. Interferon (INF)-free antiviral therapy in cirrhotic patients infected with hepatitis $\mathrm{c}$ on the waiting list for liver transplantation. efficacy and impact on delisting and liver function [abstract FRI464]. Proceedings of the 51st Annual Meeting of the European Association for the Study of the Liver (EASL); 2016 Apr. 13-17; Barcelona, Spain.

71. Islam N, Krajden M, Shoveller J, et al. Incidence, risk factors, and prevention of hepatitis C reinfection: a population-based cohort study. Lancet Gastroenterol Hepatol 2017;2:200-10

72. Swain MG, Lai MY, Shiffman ML, et al. A sustained virologic response is durable in patients with chronic hepatitis $C$ treated with peginterferon alfa-2a and ribavirin. Gastroenterology 2010;139:1593-601.

73. Sarrazin C, Isakov V, Svarovskaia ES, et al. Late relapse versus hepatitis C virus reinfection in patients with sustained virologic response after sofosbuvirbased therapies. Clin Infect Dis 2017;64:44-52.

74. Martin NK, Vickerman P, Dore GJ, et al. Prioritization of HCV treatment in the direct-acting antiviral era: an economic evaluation. J Hepatol 2016;65:17-25.

75. Singal AG, Pillai A, Tiro J. Early detection, curative treatment, and surviva rates for hepatocellular carcinoma surveillance in patients with cirrhosis: a meta-analysis. PLoS Med 2014;11:e1001624.

76. Janjua NZ, Chong M, Kuo M, et al. Long-term effect of sustained virological response on hepatocellular carcinoma in patients with hepatitis $\mathrm{C}$ in Canada. J Hepatol 2017;66:504-13.

77. El-Serag HB, Kanwal F, Richardson P, et al. Risk of hepatocellular carcinoma after sustained virological response in veterans with hepatitis $\mathrm{C}$ virus infection. Hepatology 2016;64:130-7.

78. D'Ambrosio R, Aghemo A, Rumi MG, et al. Persistence of hepatocellular carcinoma risk in hepatitis $C$ patients with a response to IFN and cirrhosis regression. Liver Int 2018 Jan. 27 [Epub ahead of print].

79. D’Ambrosio R, Degasperi E, Aghemo A, et al. Serological tests do not predict residual fibrosis in hepatitis $\mathrm{C}$ cirrhotics with a sustained virological response to interferon. PLoS One 2016;11:e0155967. 
80. Reig M, Mariño Z, Perelló C, et al. Unexpected high rate of early tumor recurrence in patients with HCV-related HCC undergoing interferon-free therapy. $J$ Hepatol 2016;65:719-26.

81. Conti F, Buonfiglioli F, Scuteri A, et al. Early occurrence and recurrence of hepatocellular carcinoma in HCV-related cirrhosis treated with direct-acting antivirals. J Hepatol 2016;65:727-33.

82. Bourlière M, Gordon SC, Flamm SL, et al. Sofosbuvir, velpatasvir, and voxilaprevir for previously treated HCV infection. N Engl J Med 2017;376:2134-46.

83. Poordad F, Pol S, Asatryan A, et al. Glecaprevir/pibrentasvir in patients with hepatitis $C$ virus genotype 1 or 4 and past direct-acting antiviral treatment failure. Hepatology 2018;67:1253-60.

84. Wong WW, Lee KM, Singh S, et al. Drug therapies for chronic hepatitis C infection: a cost-effectiveness analysis. CMAJ Open 2017;5:E97-108.

85. Wong WWL, Erman A, Feld JJ, et al. Model-based projection of health and economic effects of screening for hepatitis C in Canada. CMAJ Open 2017;5:E662-72.

86. European Association for the Study of Liver. EASL recommendations on treatment of hepatitis C. J Hepatol 2015;63:199-236.

87. AASLD/IDSA HCV Guidance Panel. Hepatitis C guidance: AASLD-IDSA recommendations for testing, managing, and treating adults infected with hepatitis $C$ virus. Hepatology 2015;62:932-54.
88. Grad R, Thombs BD, Tonelli M, et al.; Canadian Task Force on Preventive Health Care. Recommendations on hepatitis C screening for adults. CMAJ 2017;189:E594-604.

89. Smith BD, Morgan RL, Beckett GA, et al. Recommendations for the identification of chronic hepatitis C virus infection among persons born during 19451965. MMWR Recomm Rep 2012;61(RR-4):1-32.

90. Bottero J, Brouard C, Roudot-Thoraval F, et al. 2014 French guidelines for hepatitis $B$ and $C$ screening: a combined targeted and mass testing strategy of chronic viruses namely HBV, HCV and HIV. Liver Int 2016;36:1442-9.

91. Bolotin S, Feld JJ, Garber G, et al. Population-based estimate of hepatitis C virus prevalence in Ontario, Canada. PLoS One 2018;13:e0191184.

92. Payne E, Totten S, Archibald C. Hepatitis C surveillance in Canada. Can Commun Dis Rep 2014;40:421-8.

93. Garber G, Bolotin S. PHO Grand Rounds: Population-based estimate of hepatitis $\mathrm{C}$ virus prevalence in Ontario, Canada [Webinar]. Toronto: Public Health Ontario; 2016 Nov. 29.

94. Combating hepatitis B and C to reach elimination by 2030. Geneva: World Health Organization; May 2016. Available: http://apps.who.int/iris/bitstream/ handle/10665/206453/WHO_HIV_2016.04_eng.pdf;jsessionid=B665CA5BAF2F6 8F5A06EA95AA5EDCFDC?sequence=1 (accessed Oct. 17, 2017).
Competing interests: Hemant Shah reports personal fees from AbbVie, Gilead, BristolMyers Squibb, Intercept, Janssen, Merck, Roche and Lupin, and grants from Janssen and Boehringer Ingelheim, outside the submitted work. Marc Bilodeau reports personal fees from AbbVie, Gilead, GSK, Merck, Vertex and Roche, and grants from Merck and GSK, during the conduct of the study, and reports grants from Synageva, Verlyx and BristolMyers Squibb, and personal fees from Verlyx, outside the submitted work. Kelly Burak reports grants from Bayer, Verlyx and Lupin, and personal fees from Merck, Astellas, Bayer, Gilead and Amgen, outside the submitted work. Curtis Cooper reports grants and personal fees from Gilead, Merck and AbbVie, outside the submitted work. Marina Klein reports grants from ViiV Healthcare, Merck and Janssen, and consulting fees from ViiV Healthcare, BristolMyers Squibb, AbbVie and Merck. Alnoor Ramji reports a grant from Gilead; personal fees for clinical trials from AbbVie, Gilead, Janssen, Intercept, Lupin and Merck; and other fees from AbbVie, Bristol-Myers Squibb, Allergen, Gilead,
Janssen, Intercept, Novartis and Merck, outside the submitted work. Dan Smyth reports personal fees from AbbVie, Merck and Gilead, and grants from AbbVie and Gilead, outside the submitted work. Jordan Feld reports grants and personal fees from AbbVie, Merck, Gilead and Janssen; personal fees from Contravir; and grants from Abbott, outside the submitted work. No other competing interests were declared.

This article has been peer reviewed.

Affiliations: Toronto Centre for Liver Disease (Shah, Feld), Toronto Western and General Hospital, University Health Network, University of Toronto, Toronto, Ont.; Department of Medicine, Liver Unit (Bilodeau), Centre hospitalier de l'Université de Montréal, Montréal, Que.; Department of Medicine, Liver Unit, Division of Gastroenterology and Hepatology (Burak), University of Calgary, Calgary, Alta.; Division of Infectious diseases (Cooper), Ottawa Hospital Research Institute, University of Ottawa, Ottawa, Ont.; Division of Infectious Diseases and Chronic Viral Illness Service Glen site (Klein), McGill University Health Centre Montréal, Que.; Department of Medicine, Division of Gastroenterology (Ramji), University of British Columbia, Vancouver, BC; Division of Infectious Disease (Smyth), Dalhousie University, Moncton Hospital, Moncton, NB

Contributors: The nominated guideline committee co-chairs (Hemant Shah, Jordan Feld) structured and coordinated the development process of the guideline. All of the authors contributed to the final design of the work, and the acquisition, analysis and interpretation of data. All of the authors drafted the manuscript, revised it critically for important intellectual content, gave final approval of the version to be published and agreed to be accountable for all aspects of the work.

Acknowledgements: The authors thank Colleen Manitt for her assistance with editing and proofreading the document.

Correspondence to: Hemant Shah, Hemant.Shah@uhn.ca; Jordan Feld, Jordan.Feld@uhn.ca 